\title{
Temperature Field of Concrete Cured in Winter Conditions Using Thermal Control Measures
}

\author{
Tuo Shi $\mathbb{D}^{1,2,3}$ Chunlin Deng, ${ }^{1,2,3}$ Jiaqi Zhao, ${ }^{1,2,3}$ Pingxiang Ding, ${ }^{1,2,3}$ and Zhihong Fan ${ }^{1,2,3}$ \\ ${ }^{1}$ Key Laboratory of Communication Industries for Durability Technology of Hydraulic Structures, Guangzhou 510230, China \\ ${ }^{2}$ China Communications Construction Fourth Harbour Engineering Research Institute Co., Ltd., Guangzhou 510230, China \\ ${ }^{3}$ Southern Marine Science and Engineering Guangdong Laboratory, Zhuhai 519080, China
}

Correspondence should be addressed to Tuo Shi; 1179848174@qq.com

Received 22 September 2021; Revised 26 December 2021; Accepted 3 January 2022; Published 18 January 2022

Academic Editor: Lingxue Kong

Copyright (c) 2022 Tuo Shi et al. This is an open access article distributed under the Creative Commons Attribution License, which permits unrestricted use, distribution, and reproduction in any medium, provided the original work is properly cited.

\begin{abstract}
In order to obtain the construction technology of concrete construction at extreme low temperature and ensure the construction quality of concrete in winter, this study investigated the temperature field and compressive performance of concrete specimens cured in the laboratory at a temperature of $-10^{\circ} \mathrm{C}$ using different thermal control measures. A finite element model of the observed temperature field was then established and shown to be in good agreement with the test results. This model was applied to analyse the factors influencing thermally controlled low-temperature concrete curing in winter. The results showed that concrete cast at $-10^{\circ} \mathrm{C}$ using rock wool insulation covering and heated formwork for thermal control met the relevant performance requirements. Finally, the proposed temperature field model and thermal control measures were successfully applied to the construction of a concrete box girder in winter conditions.
\end{abstract}

\section{Introduction}

When the outdoor daily average temperature is below $5^{\circ} \mathrm{C}$ for five consecutive days, concrete casting is classified as a winter construction activity [1]. Owing to the requirements of aggressive construction scheduling, it was necessary to cast the box girders for a bridge project during the winter in northern China, which can be quite cold with an average temperature below $0^{\circ} \mathrm{C}[2]$.

When the ambient temperature drops below $0^{\circ} \mathrm{C}$, the free water inside of fresh concrete will freeze, leading to a volumetric expansion of about $9 \%$. The stress induced by the formation of large ice crystals can readily expand and crack the concrete, resulting in internal deterioration of concrete. In addition, the hydration of cementitious materials inside the concrete is considerably reduced in a low-temperature environment; as the temperature drops below zero, the hydration process of cementitious materials slows down or even stops, resulting in irreparable damage to the concrete.

At curing temperatures below $5^{\circ} \mathrm{C}$, concrete compressive strength has been observed to develop particularly slowly with curing time. Indeed, after curing at $3^{\circ} \mathrm{C}$ for $7 \mathrm{~d}$, the compressive strength will only reach about $80 \%$ of that achieved by standard curing at $20^{\circ} \mathrm{C}$ for $7 \mathrm{~d}$ [3]. When the ambient temperature is $0^{\circ} \mathrm{C}$, the final $28 \mathrm{~d}$ strength of mass concrete heated by only the process of hydration will only reach about $70 \%$ of that achieved by standard curing [4]. Thus, the low-temperature environment is not conducive to the strength development and rapid production of concrete structures [5]. As a result, a great deal of research has been conducted to investigate the specific effects of low-temperature curing conditions on concrete characteristics and identify methods to mitigate those effects.

Melnik [6] used the three-dimensional unsteady temperature field mathematical model to calculate concrete strength when cured in winter. Marzouk and Hussein [7] found the compressive strength of high-strength concrete to be directly proportional to the applied curing temperature. Khatib [8] studied the effect of low-temperature curing on the compressive strength of metakaolin concrete and found that the optimal quantity of metakaolin not only improved the concrete strength but also reduced the shrinkage. Barna 
et al. [9] and Karagol et al. [10] found that concrete containing antifreeze can be cured at low temperatures and still meet the design requirements. El-Hassan et al. [11] studied the performance of alkali slag concrete using different curing systems and found that indirect water curing improved the compressive strength. Consoli et al. [12] reported that increasing the curing temperature can improve the compressive strength and splitting tensile strength of a sand/ coal/fly ash/lime mixture, and Zhang et al. [13] found that an increase in curing temperature from $5^{\circ} \mathrm{C}$ to $50^{\circ} \mathrm{C}$ accelerated the hydration of cement. Korhonen [14] concluded that the low-temperature admixture standard proposed by the American Society of Civil Engineering should be widely applied. Shi et al. [15] simulated the change in hydration heat of concrete components over time when curing at low temperatures using the finite element method to obtain an effective prediction model. Yao et al. [16] studied the temperature field and temperature stress in a single-chamber box girder heated by warm air inside the girder when cast in winter, finding that the considered measures could be applied to effectively realise winter concrete construction. Choi et al. [17] and Zhang et al. [18-20] got good results by applying new materials to concrete construction based on the study of concrete properties at low temperatures.

In previous studies, the temperature field and strength of concrete were studied when casting at low temperatures of $5-10^{\circ} \mathrm{C}$. However, the casting of concrete at temperatures below $0^{\circ} \mathrm{C}$ has been considered less often. The method evaluated by Yao et al. [16] could be effective in subfreezing temperatures, but the use of hot air inside a box girder duct is necessarily limited to the casting of box girder structures. At present, little research has been published investigating the impact of comprehensive thermal control measures such as heated formwork, a cast-in electric heating band, and rock wool insulation covering on concrete construction in winter. Therefore, in this paper, the temperature fields in concrete structures protected by these comprehensive thermal control measures were investigated when casting at a constant temperature of $-10^{\circ} \mathrm{C}$, and the resulting mechanical properties were analysed to quantify their effects and inform a finite element simulation of the temperature field for use in the design of winter casting processes.

\section{Materials and Methods}

The design strength of the concrete used in the specimens evaluated in this study was C55, and the mix contents and their proportions are given in Table 1. The cementitious materials were p.052.5 ordinary Portland cement from Laishui Jinyu Jidong Environmental Protection Technology Co. Ltd. and mineral powder grade S95 granulated blast furnace slag from Hebei Qianjin Metallurgical Technology Co. Ltd. The fine aggregate was medium sand from the zone II sand quarry production of Zhangjiakou Futai Mining Co. Ltd., and the coarse aggregate was gravel produced by Laishui Shunhe Building Materials Co. Ltd. Finally, the superplasticiser was a polycarboxylic acid superplasticiser from Subot Co. Ltd.

The test specimens were $70 \mathrm{~cm} \times 70 \mathrm{~cm} \times 50 \mathrm{~cm}$ concrete prisms. The ambient temperature was set to $-10^{\circ} \mathrm{C}$, and the casting temperature was about $8^{\circ} \mathrm{C}$. The thermal control measures evaluated in this study included (1) rock wool thermal insulation, (2) heated steel formwork, and (3) cast-in electric heating band, considered individually and in several combinations, as shown by the experimental scheme given in Table 2. Schematics of the specimens with their thermal control measures are shown in Figure 1.

The thermal control measures applied in this study are shown in Figure 2 and described as follows. (1) Rock wool insulation: a layer of rock wool thermal insulation material was wrapped around the outside of the specimen to reduce heat loss. (2) Heated steel formwork: a continuous resistance wire was attached to the steel formwork following a helical path with $10 \mathrm{~cm}$ between runs to heat the steel and thus the concrete within using electrical power. (3) Cast-in electric heating band: a thermoelectric belt was shaped into a spiral with a diameter of $2 \mathrm{~cm}$ and a pitch of $5 \mathrm{~cm}$ and cast inside the concrete to generate internal heat when powered. Note that in this study, the heated steel formwork and electric heating band were powered on at the completion of pouring and turned off after $5 \mathrm{~d}$ of continuous heating to provide heat during the peak of hydration.

The layout of temperature measurement points of each test specimen is shown in Figure 3. The temperature was measured at each point using a resistance-based temperature sensor with a range of $-40^{\circ} \mathrm{C} \sim 200^{\circ} \mathrm{C}$ and a measurement accuracy of $0.1^{\circ} \mathrm{C}$. An automatic data acquisition system was applied to collect data every $30 \mathrm{~min}$.

To verify the effect of each thermal control measure, rebound hammer and drill core sample compressive strength tests were conducted on each specimen after $28 \mathrm{~d}$ of curing. The latter were conducted using $100 \mathrm{~mm}$ long and $100 \mathrm{~mm}$ diameter cylindrical drill core samples collected from the specimen locations shown in Figure 4.

For comparison, a batch of standard test cubes was also cast using the same mix proportions shown in Table 1 and cured under standard conditions of $20^{\circ} \mathrm{C}$ and $95 \%$ humidity for compressive strength testing after $28 \mathrm{~d}$.

\section{Results}

The temperature field measurements collected from specimens 1 to 4 are shown in Figure 5.

The temperature at each measurement point in specimen 1 can be observed to have initially increased to a peak hydration temperature of $30.4^{\circ} \mathrm{C}$ at the core location (T3) after $37 \mathrm{~h}$ before declining and finally approaching the ambient temperature. In specimens 2,3 , and 4 , the temperature at each measurement point increased much faster to much higher levels, reaching peak hydration temperatures of $66.3^{\circ} \mathrm{C}, 53.5^{\circ} \mathrm{C}$, and $68.0^{\circ} \mathrm{C}$, respectively, at $\mathrm{T} 3$ after $35 \mathrm{~h}$. The presence of the thermal control measures then clearly slowed the decrease in specimen temperatures until they were discontinued after $5 \mathrm{~d}$, when the temperatures of the specimens began to decrease rapidly.

To analyse the variation and characteristics of the hydration temperature field of each specimen, key data from the test results at $\mathrm{T} 3$ are compared in Table 3. 
TABLe 1: Mix proportions $\left(\mathrm{kg} / \mathrm{m}^{3}\right)$.

\begin{tabular}{lccccc}
\hline Water & Cement & Mineral powder & Coarse aggregate & Fine aggregate & Water-reducing agent \\
\hline 154 & 465 & 32 & 1085 & 693 & 5.88 \\
\hline
\end{tabular}

TABLE 2: Experimental scheme.

\begin{tabular}{lr}
\hline Specimen no. & Applied thermal control measures \\
\hline 1 & (1) Rock wool insulation \\
2 & (1) Rock wool insulation and (2) heated steel formwork \\
3 & (1) Rock wool insulation and (3) cast-in electric heating band \\
4 & (1) Rock wool insulation, (2) heated steel formwork, and (3) cast-in electric heating band \\
\hline
\end{tabular}

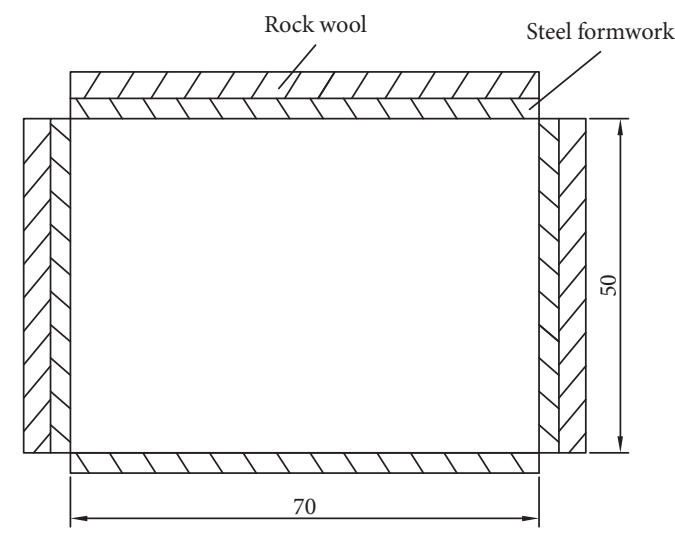

(a)

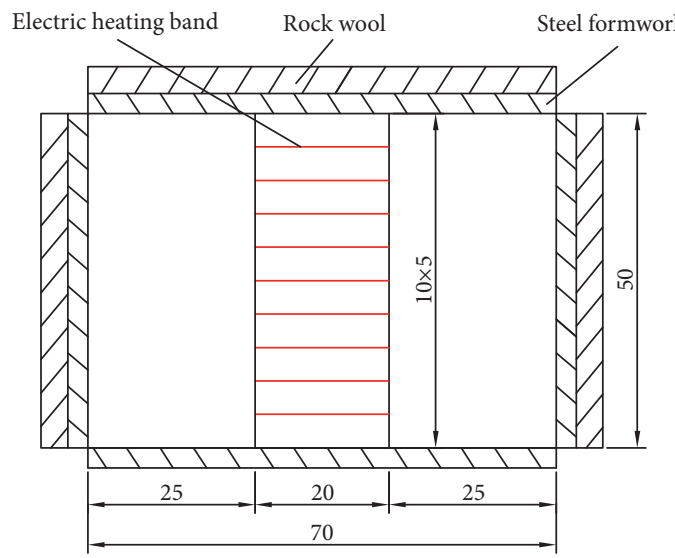

(c)

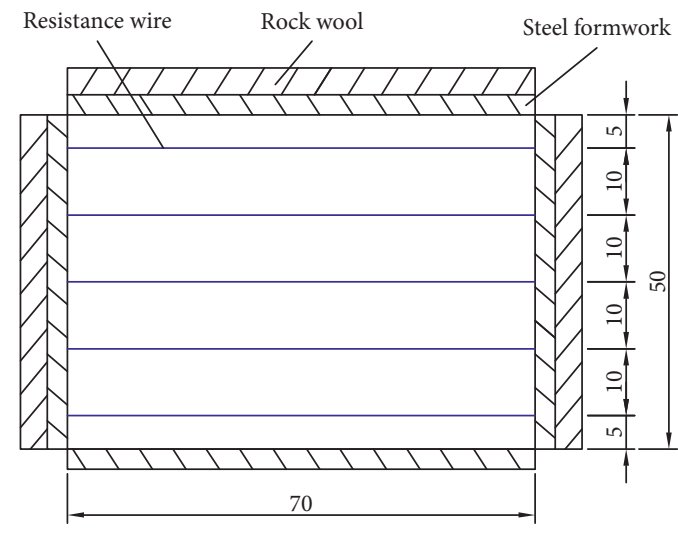

(b)

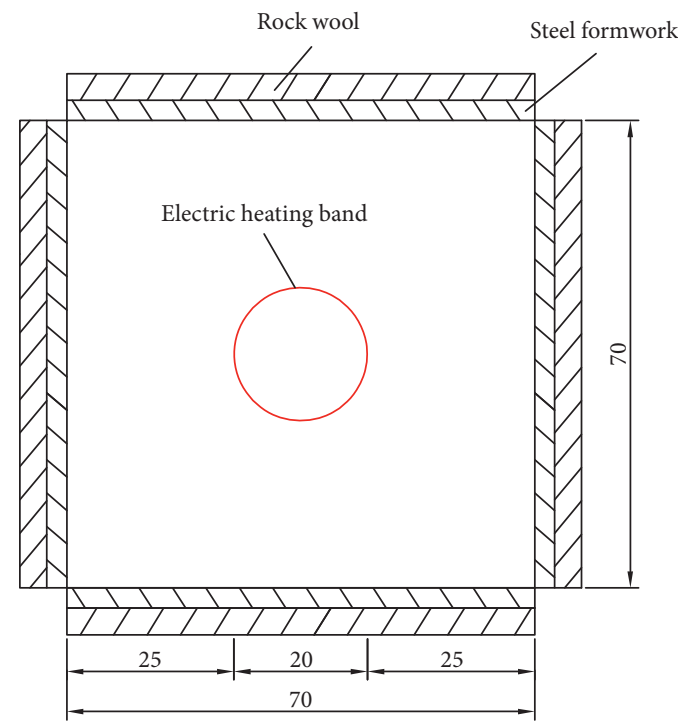

(d)

Figure 1: Continued. 


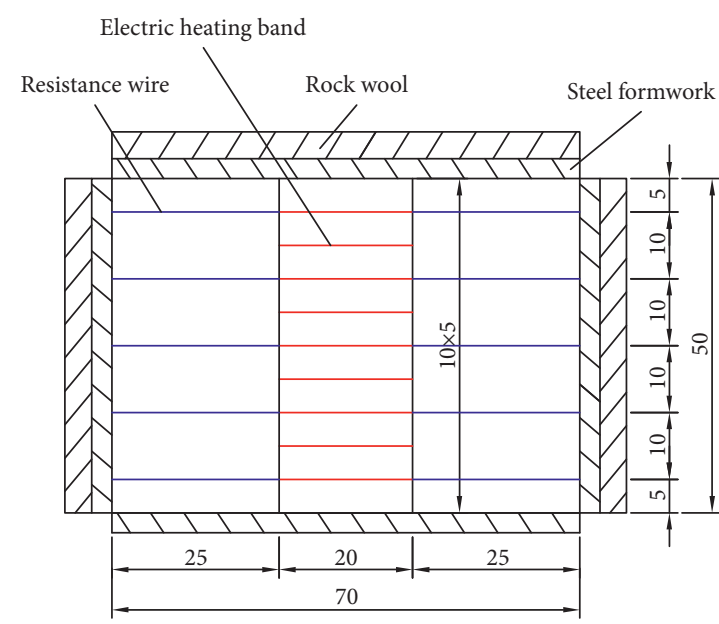

(e)

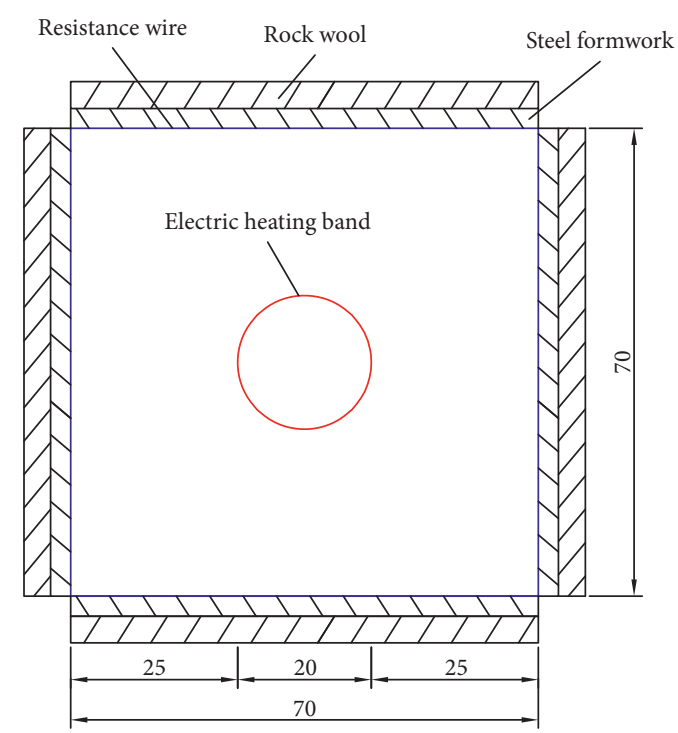

(f)

FIGURE 1: Schematic diagrams of test specimens (cm): (a) front view of specimen 1, (b) front view of specimen 2, (c) front view of specimen 3 , (d) top view of specimen 3, (e) front view of specimen 4, and (f) top view of specimen 4.

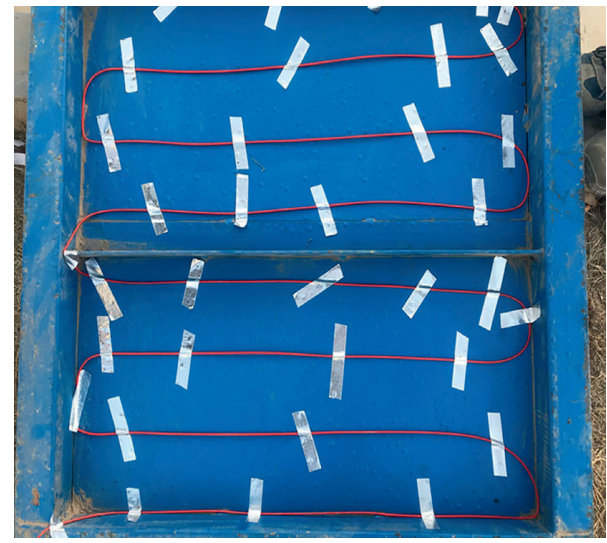

(a)

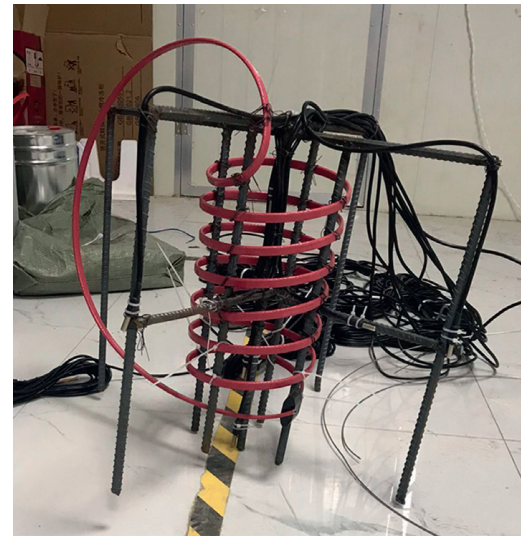

(b)

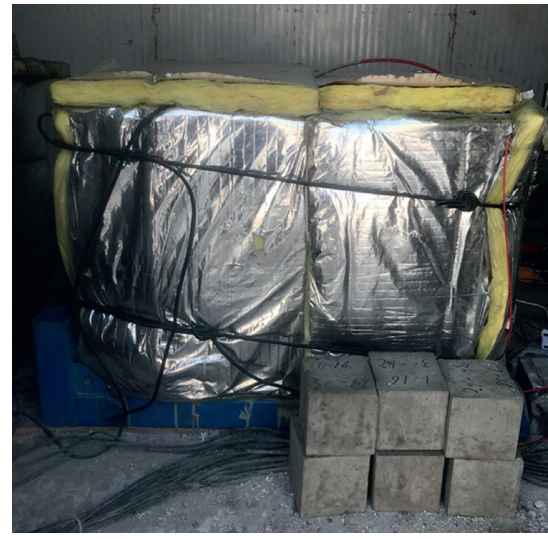

(c)

Figure 2: Photos of thermal control measures. (a) Heated steel formwork. (b) Electric heating band. (c) Test specimen wrapped in rock wool insulation.

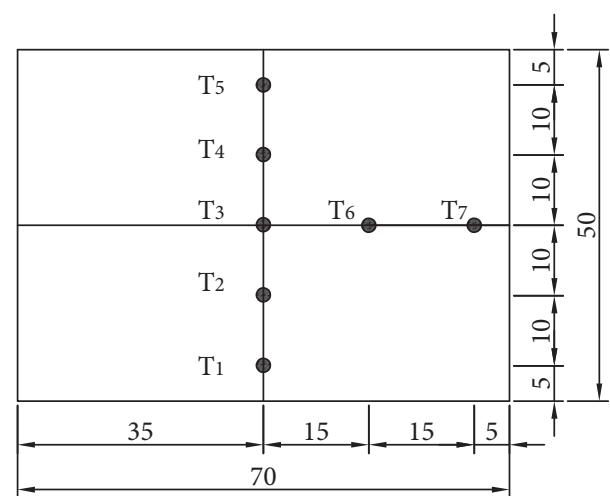

FIGURE 3: Layout of temperature measurement points $(\mathrm{cm})$.
The data in Table 3 show that the peak hydration heat at $\mathrm{T} 3$ in specimen 1 was only $30.3^{\circ} \mathrm{C}$, and its average heating rate was $0.82{ }^{\circ} \mathrm{C} / \mathrm{h}$, both of which were the lowest values among the four specimens. The corresponding $5 \mathrm{~d}$ and $7 \mathrm{~d}$ temperatures were also the lowest. This occurred because the temperature of specimen 1 was controlled only by external covering with rock wool insulation; thus, the only heat provided was generated by hydration and then lost to the low ambient temperature, resulting in an insufficient degree of hydration reaction, as reflected by the overall temperature field of the specimen.

The temperatures of specimen 2 were considerably higher than those of specimen 3, except for the maximum temperature difference, indicating that the effect of heated 


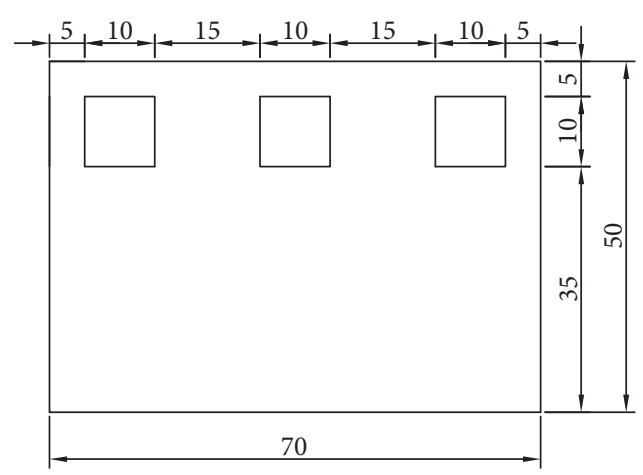

(a)

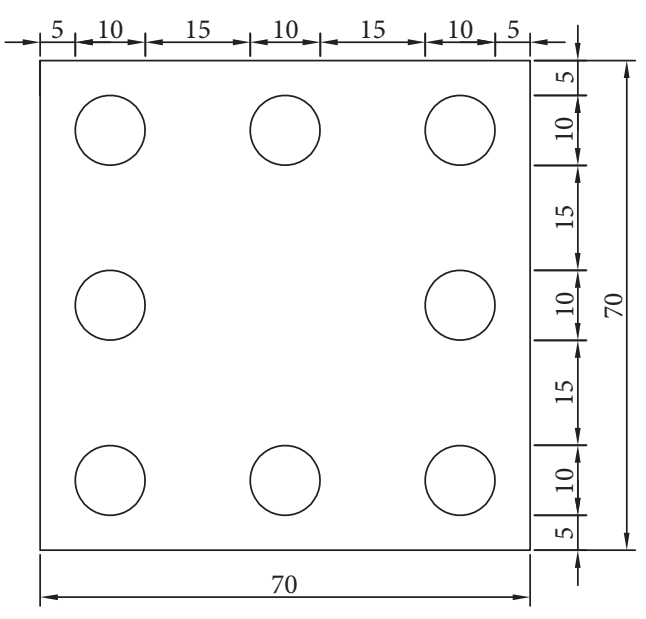

(b)

FIgURE 4: Schematic diagram of drill core sampling locations $(\mathrm{cm})$ : (a) front view and (b) top view.
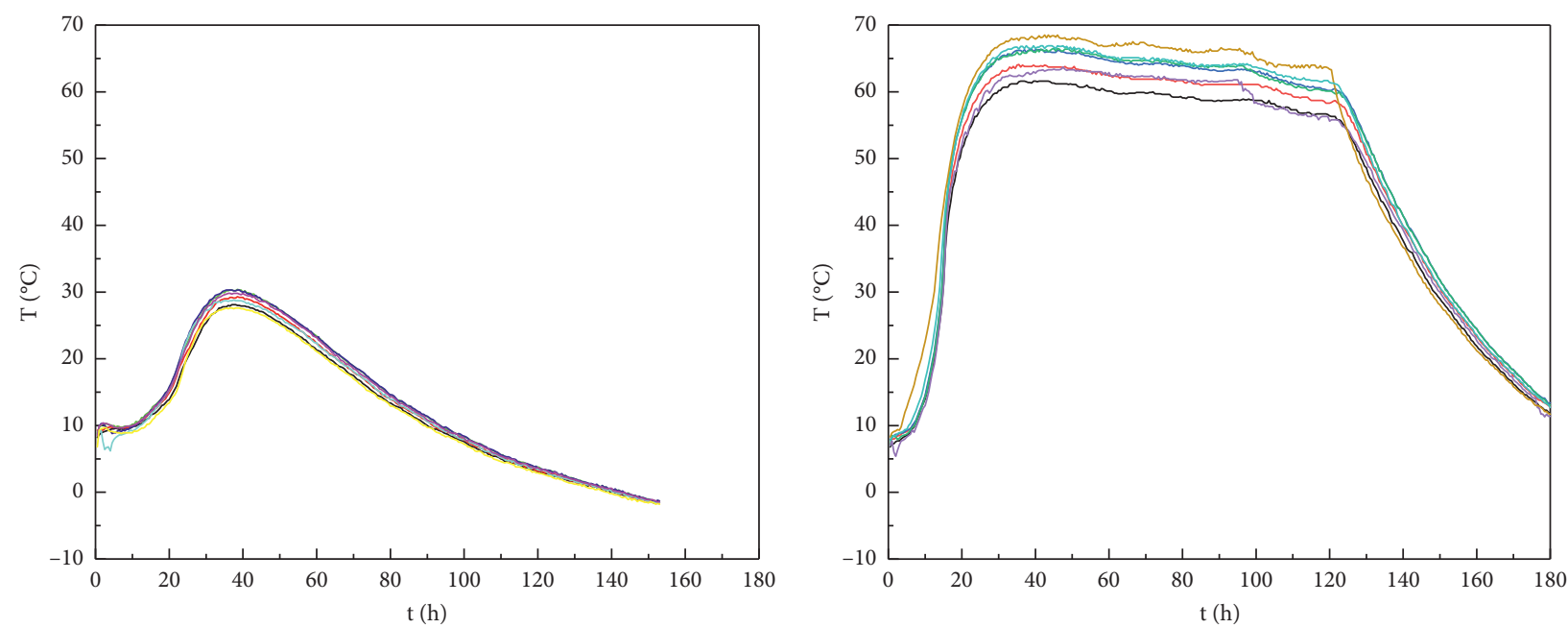

$\mathrm{T} 1$
$-\mathrm{T} 2$
$-\mathrm{T} 3$
$-\mathrm{T} 4$

$\mathrm{T} 5$
$-\mathrm{T} 6$
$\mathrm{~T} 7$

(a)

$$
\begin{array}{r}
\mathrm{T} 1 \\
-\mathrm{T} 2 \\
\mathrm{~T} 3 \\
\mathrm{~T} 4
\end{array}
$$$$
\begin{array}{r}
\mathrm{T} 5 \\
-\mathrm{T} 6 \\
\mathrm{~T} 7
\end{array}
$$

(b)

FIgUre 5: Continued. 


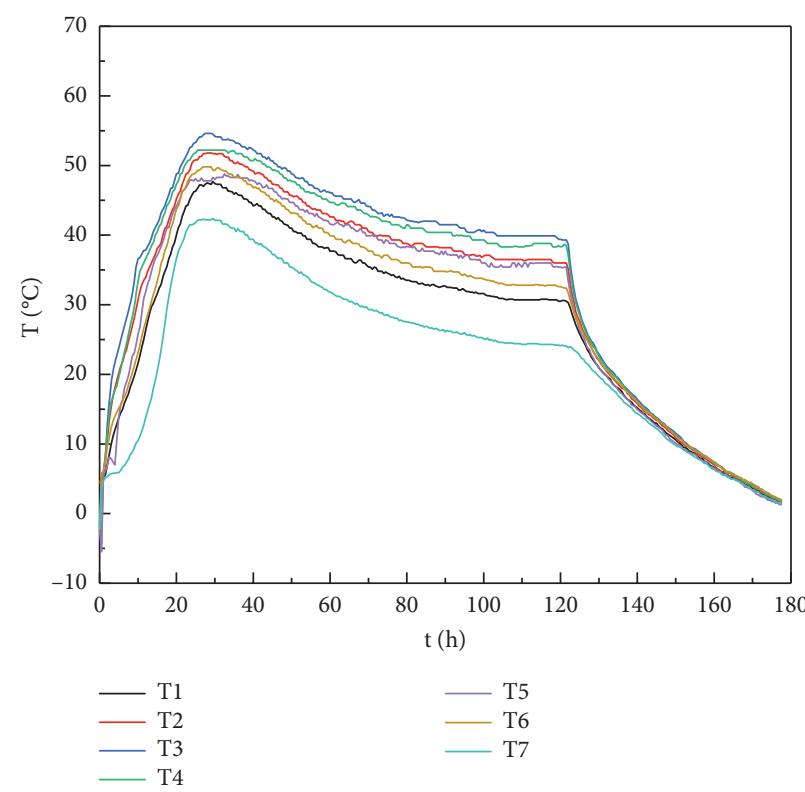

(c)

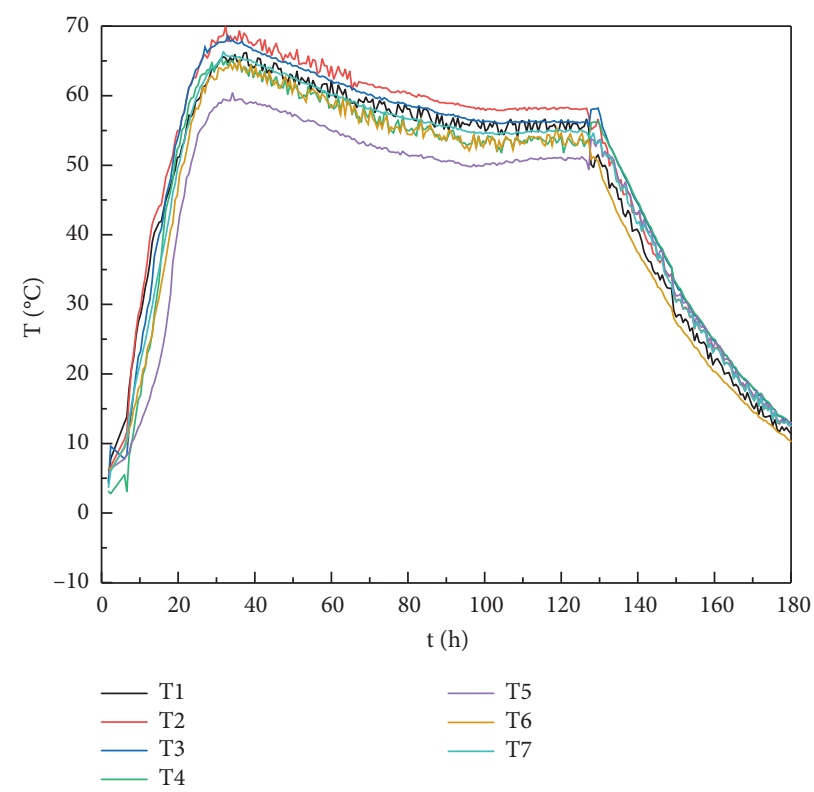

(d)

Figure 5: Temperature field measurements during hydration for (a) specimen 1, (b) specimen 2, (c) specimen 3, and (d) specimen 4.

TABLE 3: Key concrete temperature data at core measurement location T3.

\begin{tabular}{lcccccc}
\hline Specimen no. & $\begin{array}{c}\text { Peak hydration } \\
\text { heat }\left({ }^{\circ} \mathrm{C}\right)\end{array}$ & $\begin{array}{c}\text { Average heating } \\
\text { rate }\left({ }^{\circ} \mathrm{C} / \mathrm{h}\right)\end{array}$ & $\begin{array}{c}\text { Temperature at } \\
5 \mathrm{~d}\left({ }^{\circ} \mathrm{C}\right)\end{array}$ & $\begin{array}{c}\text { Average cooling } \\
\text { rate }\left({ }^{\circ} \mathrm{C} / \mathrm{h}\right)\end{array}$ & $\begin{array}{c}\text { Maximum internal/external } \\
\text { temperature difference }\left({ }^{\circ} \mathrm{C}\right)\end{array}$ & $\begin{array}{c}\text { Temperature at } \\
7 \mathrm{~d}\left({ }^{\circ} \mathrm{C}\right)\end{array}$ \\
\hline 1 & 30.3 & 0.82 & 3.8 & 0.27 & 2.7 & -1.3 \\
2 & 66.3 & 1.89 & 60.2 & 0.78 & 4.7 & 14.9 \\
3 & 54.6 & 1.82 & 39.4 & 0.66 & 15.3 & 7.3 \\
4 & 68.0 & 1.92 & 60.3 & 0.80 & 15.3 \\
\hline
\end{tabular}

steel formwork was superior to that of the cast-in electric heating band.

The differences between the temperatures of specimens 2 and 4 were small, indicating that rock wool insulation and heated steel formwork were sufficient to ensure thermal control; thus, there is no need to provide additional measures such as the cast-in electric heating band.

The surface rebound hammer and core drilling sample test results are shown for each specimen in Figure 6, in which it can be observed that the compressive strength measured by the rebound hammer test was consistent with that obtained by testing the drill core samples. The $28 \mathrm{~d}$ compressive strength of standard curing test cubes reached $65.1 \mathrm{MPa}$, whereas the $28 \mathrm{~d}$ compressive strengths of specimen 1 and 3 drill core samples failed to reach the design strength of $55 \mathrm{MPa}$ with values of $50.2 \mathrm{MPa}$ and $52.2 \mathrm{MPa}$, respectively. However, the $28 \mathrm{~d}$ compressive strengths of specimen 2 and 4 drill core samples were similar at $58.6 \mathrm{MPa}$ and $60.1 \mathrm{MPa}$, respectively, exceeding the design strength while remaining below the $28 \mathrm{~d}$ strength of the standard curing test cubes. These results indicate that the combined application of rock wool insulation and heated steel formwork can ensure that the strength of a concrete structure cast at $-10^{\circ} \mathrm{C}$ will meet the design requirements.

\section{Finite Element Simulation}

4.1. Construction and Verification of Finite Element Model. A finite element model of the temperature field in curing concrete was established using the ANSYS software package to study the factors influencing the curing of concrete in winter conditions when applying thermal control measures. This model comprised the concrete test specimen, steel formwork, and rock wool insulation, all of which were modelled using the solid70 element. The thermodynamic parameters of each material were defined as shown in Table 4 . The completed model contained 374880 nodes and 359110 units and is shown in Figure 7.

The temperature of the cast concrete in the model was set to $8^{\circ} \mathrm{C}$, and the ambient temperature was set to $-10^{\circ} \mathrm{C}$ to match the test conditions. The thermal control measures applied were consistent with those for specimen 2: the rock wool thermal insulation, modelled as discussed previously, and heated steel formwork. The changes in temperature over time at the representative core location (T3) and edge location (T7) were selected for analysis, and the results of the finite element simulation were compared with those of the test in Figure 8. The results show that the finite element simulation results were basically consistent with the 


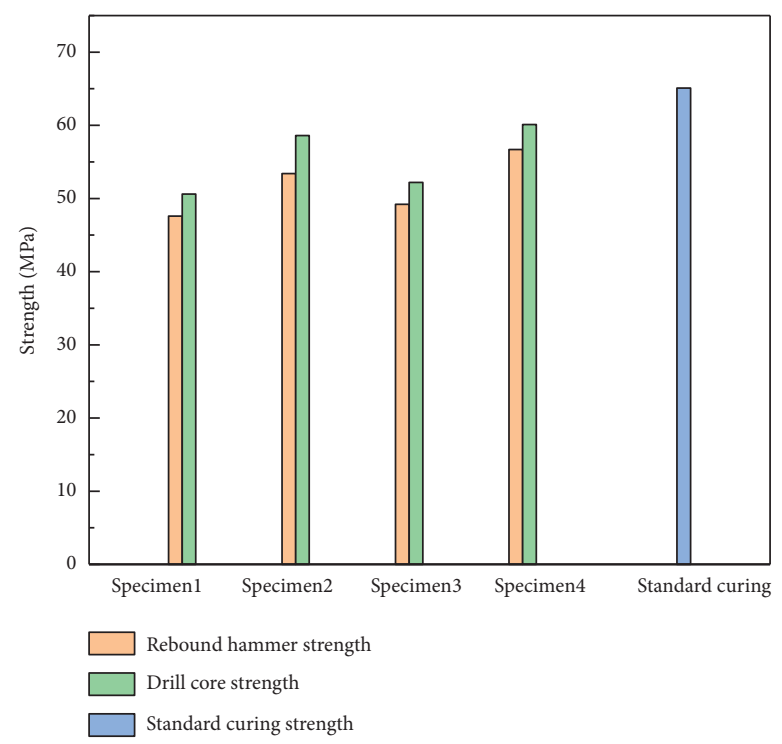

Figure 6: Comparison of test specimen strength results.

TABLE 4: Thermal parameters of materials.

\begin{tabular}{lccc}
\hline Materials & Density $\left(\mathrm{kg} / \mathrm{m}^{3}\right)$ & Specific heat capacity $\left(\mathrm{kJ} / \mathrm{m}^{3} \cdot{ }^{\circ} \mathrm{C}\right)$ & Thermal conductivity $\left(\mathrm{kJ} / \mathrm{m} \cdot \mathrm{h} \cdot{ }^{\circ} \mathrm{C}\right)$ \\
\hline Concrete & 2450 & 0.98 & 10.09 \\
Steel & 7850 & 0.45 & 199.12 \\
Rock wool & 1490 & 1.22 & 0.72 \\
\hline
\end{tabular}

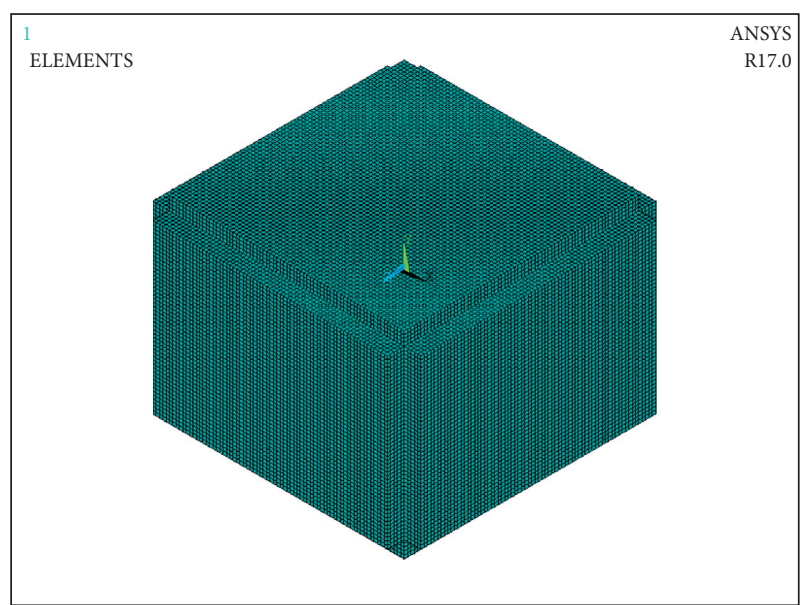

FIGURE 7: Finite element model.

experiment results, confirming the accuracy of the temperature field model established in this study.

\section{Analysis of Influencing Factors}

The finite element model was used to study the effects of different ambient temperatures, casting temperatures, and specimen sizes on the temperature field distribution and change in concrete temperature over time owing to the rock wool insulation and heated formwork thermal control measures. In these simulations, the heated formwork was applied for $5 \mathrm{~d}$ under the parameters shown in Table 5.

The changes in concrete temperature over time at locations T3 and T7 under various working conditions were selected for analysis, and the results are shown in Figures 9-11.

Figure 9 shows that when applying the rock wool insulation and heated formwork, the temperatures at T3 and T7 were less affected by the ambient temperature in the heating and stable stages but significantly affected by the ambient temperature in the cooling stage. This indicates that in the heating and stable stages, the temperature of the concrete was heavily affected by the heated formwork, which overcame the influence of the ambient temperature. However, in the cooling stage, the heated formwork was deactivated, causing the concrete temperature to slowly decrease until it was consistent with the ambient temperature. The lower the ambient temperature, the faster the cooling rate.

Thus, the use of rock wool insulation and heated formwork in winter conditions can provide a better environment for early age concrete curing, helping to form the appropriate early strength even at low temperatures.

Figure 10 shows that when using rock wool insulation and heated formwork, the casting temperature had little effect on the concrete temperature at T3 or T7 because the casting temperature primarily affects the rate of heat generation and peak hydration heat of the concrete. However, the applied thermal control measures quickly caused the concrete cast at different temperatures to rapidly reach the 


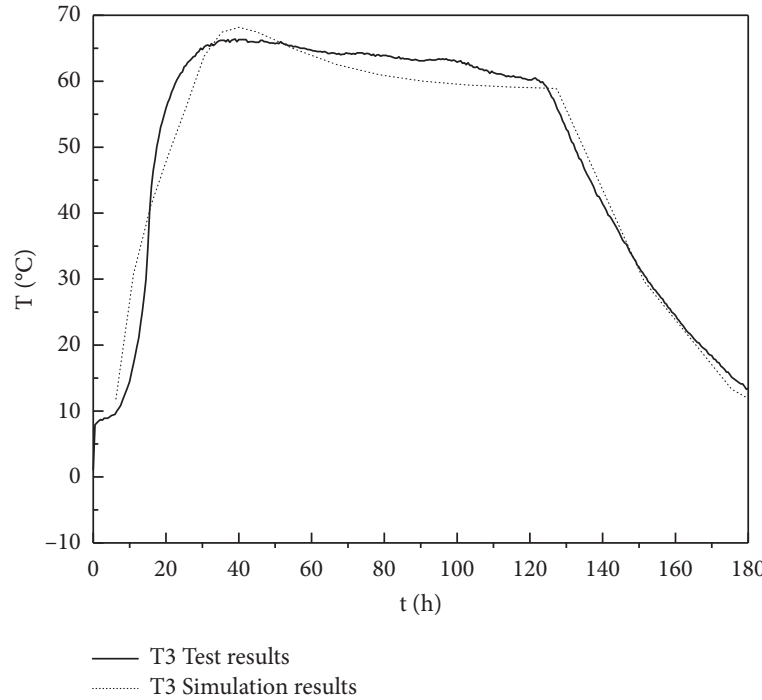

(a)

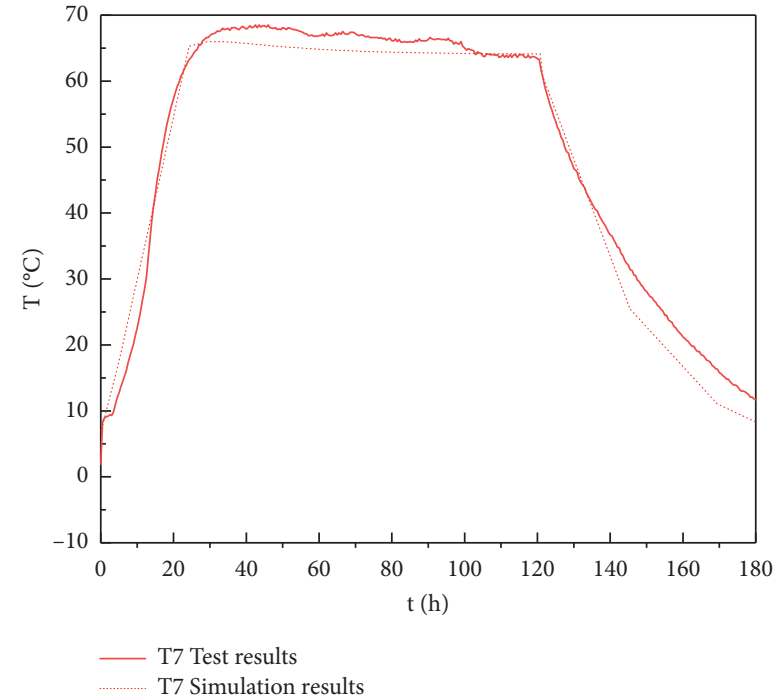

(b)

FIgURE 8: Comparison of finite element simulation results and test results at measurement locations (a) T3 and (b) T7.

TABLE 5: Temperature field simulation parameters.

\begin{tabular}{lccc}
\hline Working condition & Ambient temperature $\left({ }^{\circ} \mathrm{C}\right)$ & Casting temperature $\left({ }^{\circ} \mathrm{C}\right)$ & Specimen dimensions $(\mathrm{cm})$ \\
\hline & 0 & 10 & Size $1: 70 \times 70 \times 50$ \\
A & -10 & 10 & Size $1: 70 \times 70 \times 50$ \\
& -20 & 10 & Size $1: 70 \times 70 \times 50$ \\
& -30 & 10 & Size $1: 70 \times 70 \times 50$ \\
B & -10 & 5 & Size $1: 70 \times 70 \times 50$ \\
& -10 & 10 & Size $1: 70 \times 70 \times 50$ \\
& -10 & 15 & Size $1: 70 \times 70 \times 50$ \\
C & -10 & 20 & Size $1: 70 \times 70 \times 50$ \\
& -10 & 10 & Size $1: 70 \times 70 \times 50$ \\
& -10 & 10 & Size $2: 140 \times 140 \times 100$ \\
& -10 & 10 & Size $3: 210 \times 210 \times 150$ \\
& -10 & 10 & Size $4: 280 \times 280 \times 200$ \\
\hline
\end{tabular}

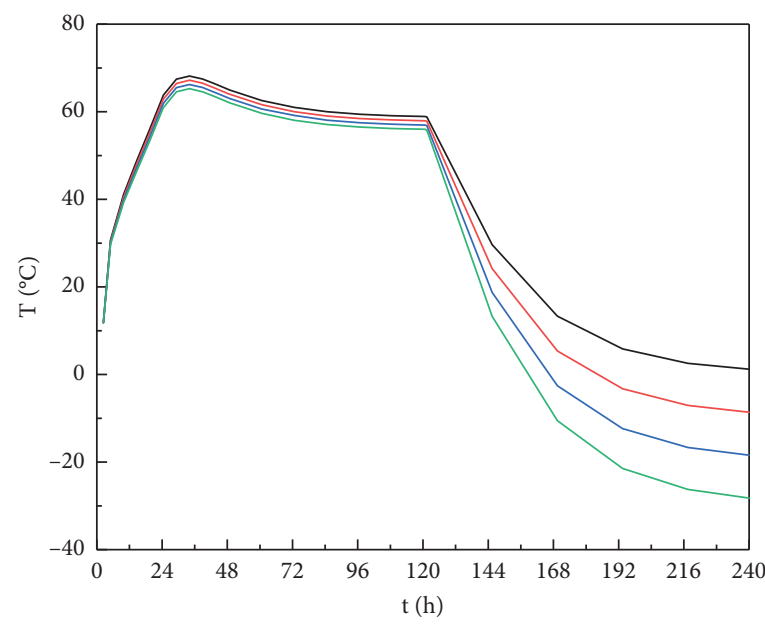

Ambient temperatures

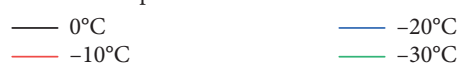

(a)

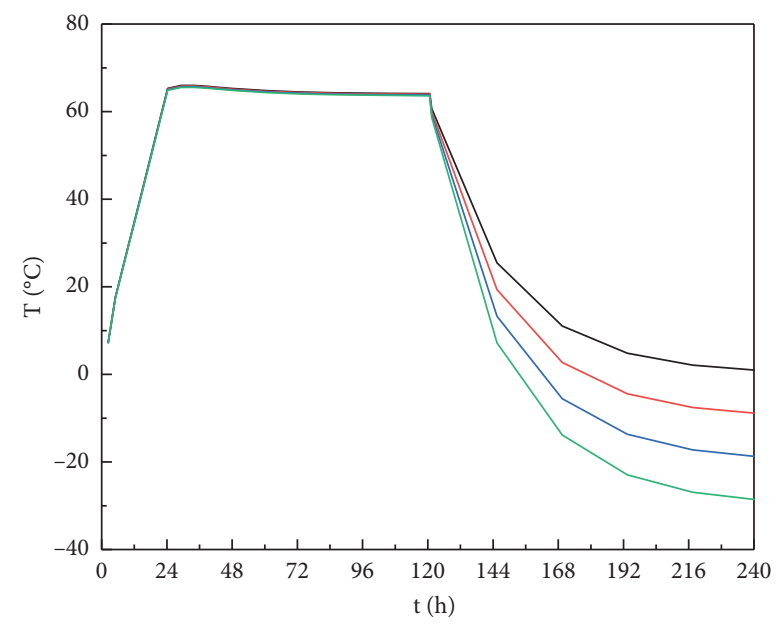

Ambient temperatures

$-0^{\circ} \mathrm{C}$

(b)

FIgURE 9: Change in concrete temperature over time according to ambient temperature at (a) T3 and (b) T7. 

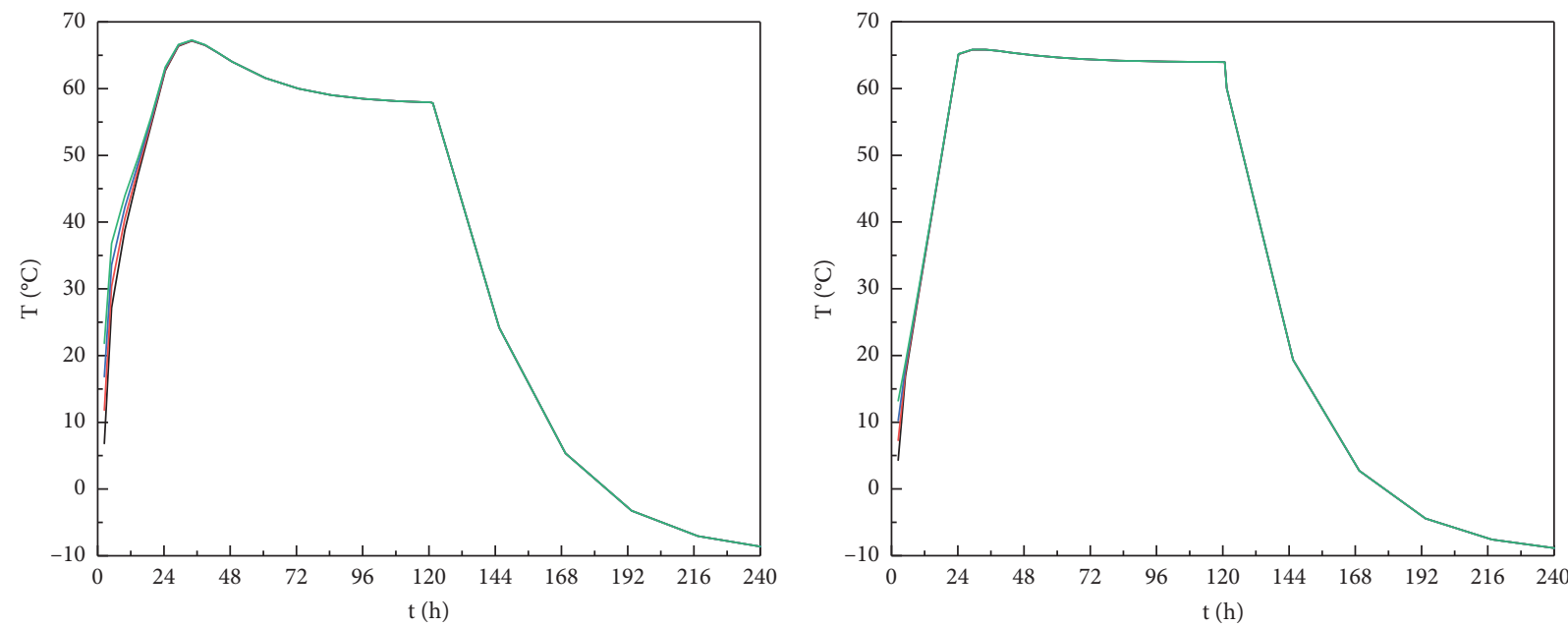

Casting temperature

$\begin{array}{ll}-5^{\circ} \mathrm{C} & -15^{\circ} \mathrm{C} \\ -10^{\circ} \mathrm{C} & 20^{\circ} \mathrm{C}\end{array}$

(a)

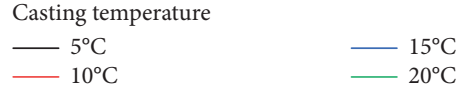

(b)

FIGURE 10: Change in concrete temperature over time according to casting temperature at (a) T3 and (b) T7.

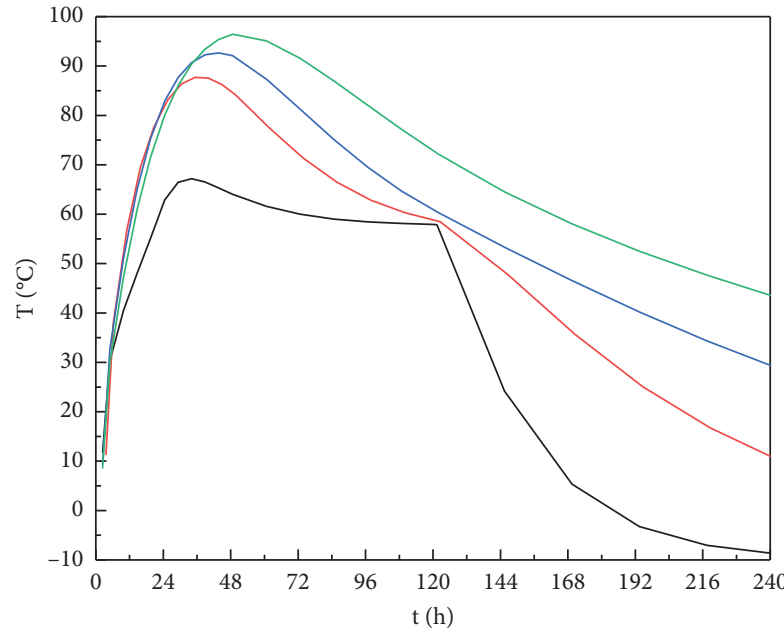

Specimen sizes

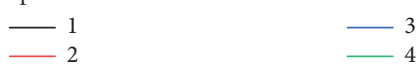

(a)

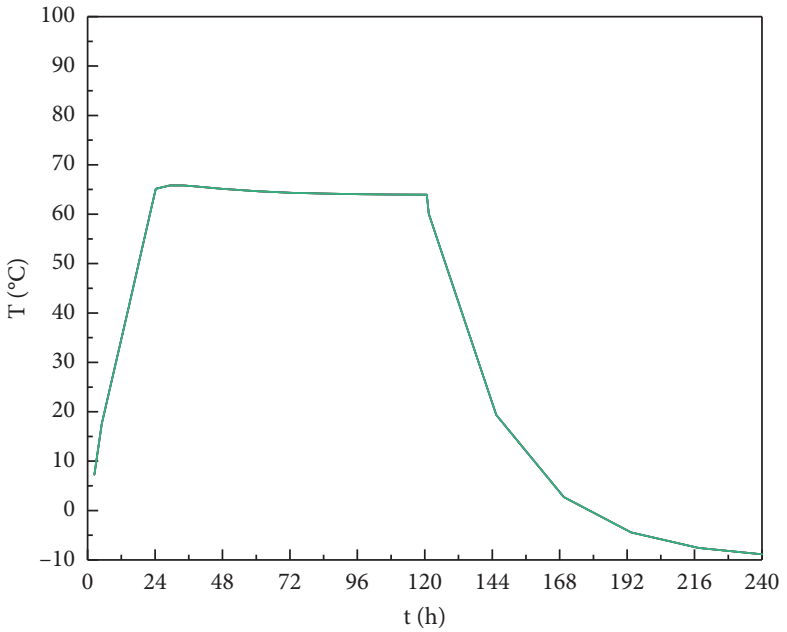

Specimen sizes

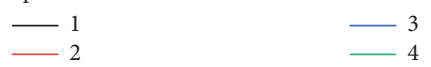

(b)

FIGURE 11: Change in concrete temperature according to specimen size at (a) T3 and (b) T7.

same curing temperature. As a result, the influence of casting temperature was very small and can be ignored.

Thus, the application of rock wool insulation and heated formwork when curing a concrete structure can obviate the need to preheat the mix and formwork beyond a convenient degree, simplifying the construction process.

Figure 11 shows that the use of rock wool insulation and heated formwork on different size specimens had a much greater impact on the concrete temperature at T3 than at T7. Indeed, when the concrete specimen was small, the temperature at the core was considerably affected by the heated formwork, showing an obvious temperature stability section. When the concrete specimen was large, T3 was far from the heated formwork and therefore less affected by it; thus, the core temperature exhibited the typical characteristics of an initial increase owing to hydration heat followed by a slow decrease. The larger the specimen size, the greater the peak value of hydration heat at T3 and the slower the subsequent cooling rate. However, at the edge of the concrete specimen, the concrete temperature was primarily 


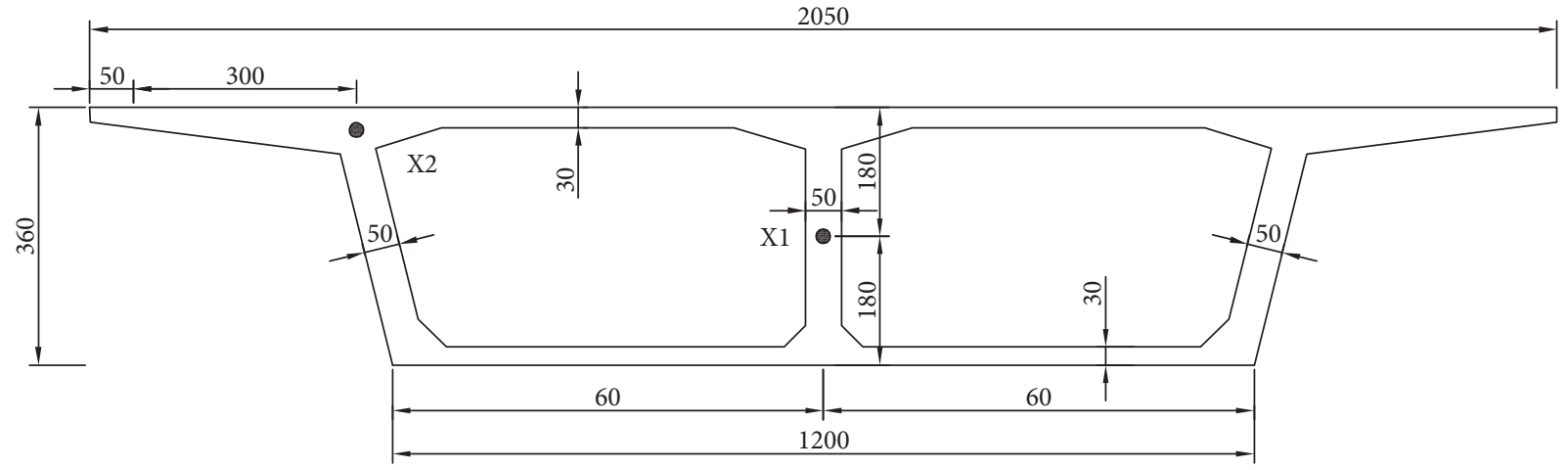

Figure 12: Box girder geometry and measurement point layout $(\mathrm{cm})$.

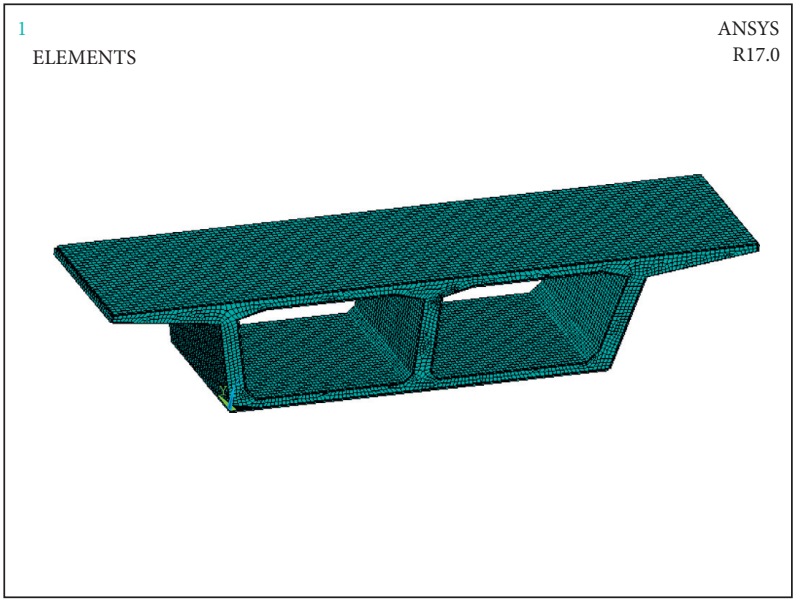

Figure 13: Box girder finite element model.

influenced by the adjacent heated formwork. As a result, the temperature at T7 was consistently higher than the ambient temperature in the early stage and thus closer to the heat of hydration in the core at T3 regardless of the size of the specimen.

Therefore, the use of rock wool insulation and heated formwork for thermal control of concrete cast in winter conditions can effectively reduce the difference between the internal and external temperatures.

In summary, the use of rock wool insulation and heated formwork to control the temperature of concrete can help to avoid the adverse effects of cold ambient curing temperatures and ensure concrete construction quality in winter.

\section{Engineering Application}

To demonstrate the engineering application of the evaluated temperature control measures, the on-site casting of box girders for a bridge project during winter is considered in this section. The average ambient temperature during casting was $-5^{\circ} \mathrm{C}$, and the minimum temperature was $-13^{\circ} \mathrm{C}$. The box girder size and measurement point layout are shown in Figure 12. First, the temperature field in the box girder was predicted using the verified finite element modelling approach with the proposed thermal control measures. The finite element model of the box girder is shown in Figure 13, and its simulated temperature field after $40 \mathrm{~h}$ of curing is shown in Figure 14. The changes in temperature over time at representative measurement points in the finite element simulation are compared in Figure 15 with data collected during an on-site curing test.

Figure 15 shows that the change in temperature over time determined using the finite element model was in good agreement with the measured results, indicating that the temperature field model proposed in this paper can effectively predict the temperature field of concrete cured in winter conditions using thermal control measures.

Finally, a rebound hammer test was conducted to determine the $28 \mathrm{~d}$ strength of the box girder, which was found to meet the design requirements. It was thus again verified that the use of the rock wool insulation and heated steel formwork thermal control measures can help to ensure appropriate construction quality of concrete cured in lowtemperature conditions. 


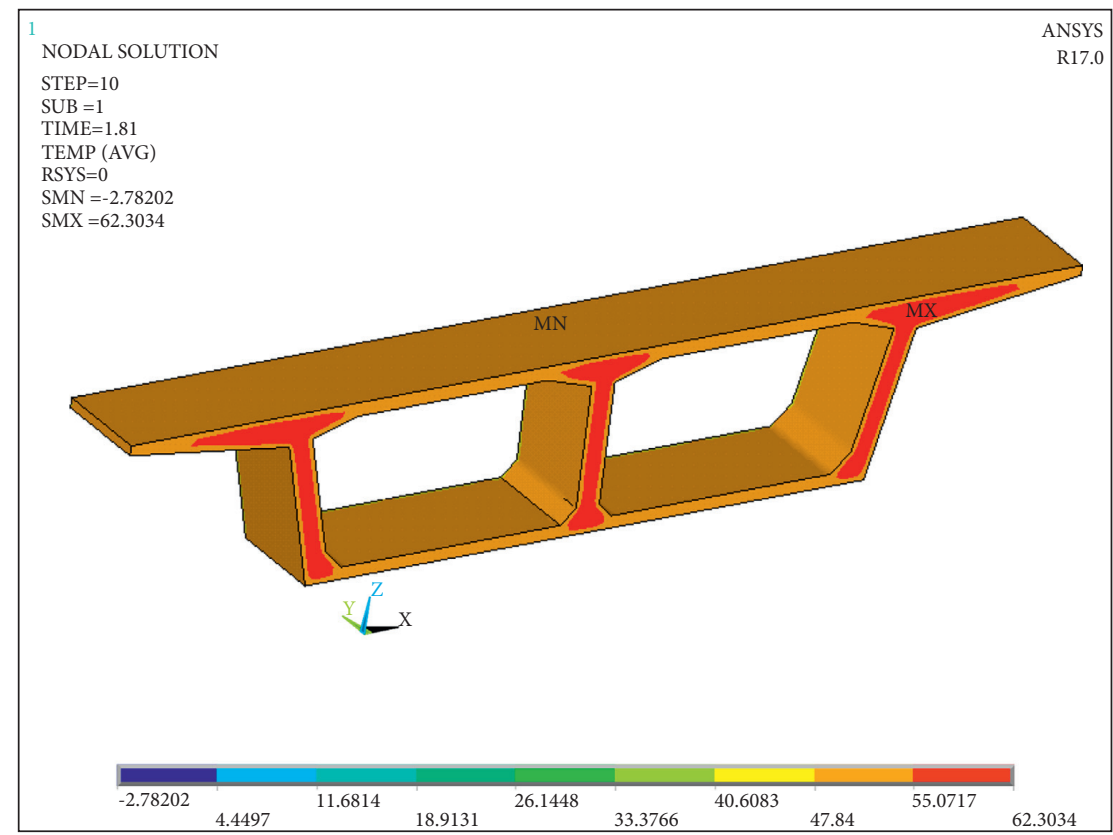

FIgURE 14: Simulated box girder temperature field after $40 \mathrm{~h}$ curing.

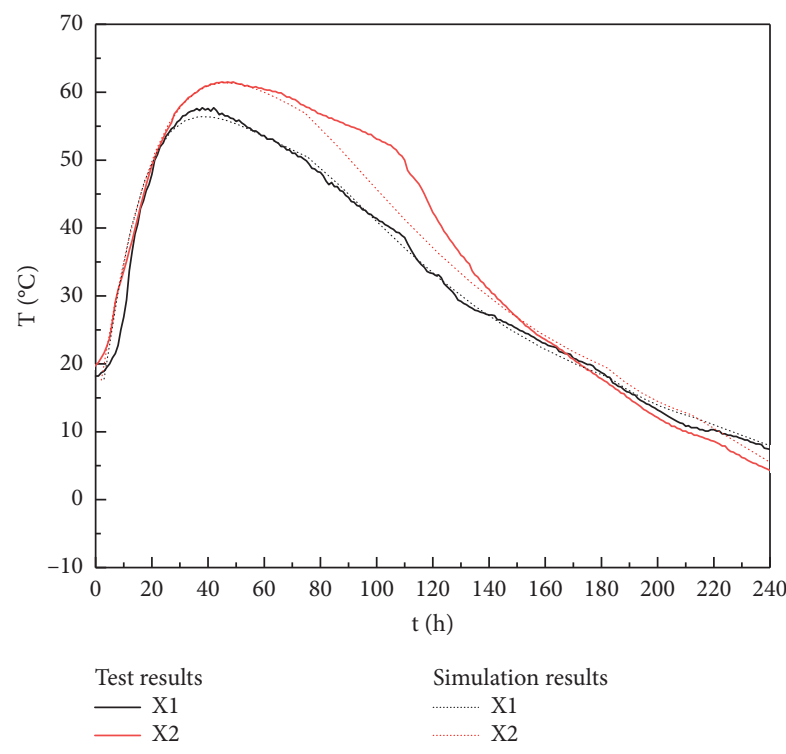

FIGURE 15: Change in temperature over time at box girder measurement points.

\section{Conclusions}

(1) The use of rock wool insulation and heated steel formwork can ensure that concrete cured at $-10^{\circ} \mathrm{C}$ will meet the design and specification requirements for structural strength and temperature difference between the inside and outside of the concrete body.

(2) The use of rock wool insulation and heated steel formwork can be readily applied to concrete construction in winter, resulting in a relatively stable temperature field regardless of concrete casting temperature, ambient temperature, or specimen size.

(3) The temperature field finite element model proposed and applied in this study accurately predicted the temperature field of concrete cured at low temperature using thermal control measures and can therefore provide a basis for the analysis of temperature problems related to concrete construction in winter conditions.

\section{Data Availability}

The data used to support the findings of this study are available from the corresponding author upon request.

\section{Conflicts of Interest}

The authors declare that they have no conflicts of interest.

\section{Acknowledgments}

The authors would like to thank China Communications Construction Fourth Harbour Second Engineering Co. Ltd. for materials used for experiments and Editage (http://www.editage. $\mathrm{cn})$ for English language editing. This research was funded by the Key Projects of Basic Research and Development of CCCC Fourth Harbor Engineering Co. Ltd. (2021-A-06-I-07).

\section{References}

[1] GB 50666-2011, Code for Construction of Concrete Structures, China Construction Industry Press, Beijing, China, 2011.

[2] Y. Chen, S. Ma, and J. Xu, "Analysis of climate change and its correlation factors in North China in recent 65 years," Journal of Hebei Normal University (Philosophy and Social Sciences Edition), vol. 45, no. 3, pp. 314-324, 2021. 
[3] S. Zhang, O. Wang, and R. Zhang, "Experimental study on strength and chloride ion permeability of concrete under different curing temperatures," Silicate Bulletin, vol. 35, no. 8, pp. 2486-2491, 2016.

[4] T. Shi, N. C. Deng, X. Guo, W. Xu, and S. Wang, "Experimental study on deformation behavior and compressive strength of concrete cast in steel tube arches under lowtemperature conditions," Advances in Materials Science and Engineering, vol. 2020, Article ID 8016282, 10 pages, 2020.

[5] JGJ/T104-2011, Code For Winter Construction Of Building Engineering, China Construction Industry Press, Beijing, China, 2011.

[6] A. A. Melnik, "Calculation of concrete strength in winter conditions based on heat exchange processes modeling," Procedia Engineering, vol. 206, pp. 831-835, 2017.

[7] H. Marzouk and A. Hussein, "Effect of curing age on highstrength concrete at low temperatures," Journal of Materials in Civil Engineering, vol. 7, no. 3, pp. 161-167, 1995.

[8] J. M. Khatib, "Low temperature curing of metakaolin concrete," Journal of Materials in Civil Engineering, vol. 21, no. 8, pp. 362-367, 2009.

[9] L. A. Barna, P. M. Seman, and C. J. Korhonen, "Energy-efficient approach to cold-weather concreting," Journal of Materials in Civil Engineering, vol. 23, no. 11, pp. 1544-1551, 2011.

[10] F. Karagol, R. Demirboga, and W. H. Khushefati, "Behavior of fresh and hardened concretes with antifreeze admixtures in deep-freeze low temperatures and exterior winter conditions," Construction and Building Materials, vol. 76, pp. 388-395, 2015.

[11] H. El-Hassan, E. Shehab, and A. Al-Sallamin, "Influence of different curing regimes on the performance and microstructure of alkali-activated slag concrete," Journal of Materials in Civil Engineering, vol. 30, no. 9, Article ID 04018230, 2018.

[12] N. C. Consoli, C. G. da Rocha, and C. Silvani, "Effect of curing temperature on the strength of sand, coal fly ash, and lime blends," Journal of Materials in Civil Engineering, vol. 26, no. 8, Article ID 06014015, 2014.

[13] D. Zhang, X. Cai, and L. Hu, "Effect of curing temperature on hydration of calcium aluminate cement-calcium sulfate-limestone system," Journal of Materials in Civil Engineering, vol. 30, no. 9, Article ID 06018011, 2018.

[14] C. Korhonen, "New developments in cold-weather concreting," in Proceedings of the 11th International Conference On Cold Regions Engineering, Anchorage, AK, USA, May 2002.

[15] T. Shi, N. C. Deng, D. Pan, and S. Wang, "Hydration heat of nonshrinkage concrete in large-diameter CFST arch ribs cured at low temperatures," Advances in Civil Engineering, vol. 2020, Article ID 8858702, 11 pages, 2020.

[16] G. Yao, Z. Yu, and G. Yang, "Temperature field and temperature stress analysis of single chamber box girder electric heater," Journal of Civil Engineering, vol. 51, no. 3, pp. 109-114, 2018.

[17] S.-H. Choi, H.-S. Lee, H.-K. Choi, K. Hyeong-chul, M. TaeBeom, and M. A. Ismail, "Experimental research on development of heated formincorporating exothermic reaction powder to protect concrete in cold weather," Construction and Building Materials, vol. 135, no. 15, pp. 30-36, 2017.

[18] G. Zhang, H. L. Yang, C. Ju, and Y. Yang, "Novel selection of environment-friendly cementitious materials for winter construction: alkali-activated slag/portland cement," Journal of Cleaner Production, vol. 258, Article ID 120592, 2020.

[19] G. Zhang, Y. Z. Yang, and H. M. Li, "Calcium-silicate-hydrate Seeds as an Accelerator for Saving Energy in Cold Weather
Concreting - Sciencedirect," Construction And Building Materials, vol. 264, Article ID 120191, 2020.

[20] G. Zhang, H. Y. Yu, H. MLi, and Y Yingzi, "Experimental study of deformation of early age concrete suffering from frost damage," Construction and Building Materials, vol. 215, pp. 410-421, 2019. 